\title{
Movimentos negros, educação e ações afirmativas
}

Sales Augusto dos Santos

Curso: Doutorado em Sociologia

Data da defesa: 7 de agosto de 2007

Orientador: Prof. Dr. Sadi Dal Rosso

\section{Resumo}

Esta tese se propõe a discutir por que renomados cientistas sociais da área de estudos e pesquisas sobre as relações raciais brasileiras - brancos em sua maioria absoluta, de acordo com a classificação do IBGE -, são contra a implementação de cotas para os estudantes negros nos vestibulares das universidades públicas brasileiras. Para responder a essa questão, o autor busca sustentar a hipótese de que a política de cotas para negros no ensino superior público brasileiro extrapola o seu objetivo imediato, qual seja, a inclusão de estudantes negros no ensino público superior. Para além da sua função manifesta, essa política tem um potencial transformador ao demonstrar que é possível redistribuir políticas públicas de boa qualidade e, adicionalmente, questionar a ideologia racial brasileira. E mais, ela possibilita que se aspire a mudanças na composição das elites dirigentes brasileiras. Todavia, no processo de verificação dessa hipótese apareceram dois novos problemas.

O primeiro deles refere-se ao papel dos Movimentos Sociais Negros (MSN) no processo de implementação das ações afirmativas. 
Para analisá-lo, buscou-se conhecer se havia significativa reivindicação por educação nas lutas desses movimentos, ou seja, levantou-se a hipótese de que a bandeira por educação pública é muito antiga na história dos MSN e que a luta por essa política pública pôde formar a base para as atuais reivindicações por ações afirmativas para os estudantes negros ingressarem no ensino público superior brasileiro.

O segundo problema - como ou por que foi possível a aprovação do sistema de cotas para estudantes negros no vestibular da UnB numa conjuntura tão adversa e hostil a esse tipo de política pública? - está imbricado com o papel dos MSN no processo de implementação do sistema de cotas.

Em suma, esta tese discute o que está sob disputa na sociedade brasileira com a implementação da política de ação afirmativa de cotas para os estudantes negros ingressarem nas universidades públicas. Conseqüentemente, discute também a luta dos MSN brasileiros por educação pública de boa qualidade em todos os níveis de ensino, ou seja, do fundamental ao superior.

Palavras-chave: movimentos negros, educação, ensino superior, ação afirmativa, sistema de cotas. 